\title{
An Investigation of Science Teachers' Teaching Methods and Techniques: Amasya Case
}

\author{
Orhan KARAMUSTAFAOĞLU*
}

\author{
Adem BAYAR **
}

Received: 28 March 2014

Accepted: 18 July 2014

\begin{abstract}
The purpose of this study is to determine the methods and techniques science teachers mostly employ in their classrooms. To collect data, the researchers employed a survey with 60 science teachers and randomly selected 6 of them to observe these selected teachers in real classroom situation. Furthermore, the researchers invited 154 students taught by the selected 6 teachers in this study, for focus group interviewing. After analyzing the collected data, the researchers found that teachers in this study 1) were more likely to use narrative method, 2) supported their teaching with question and answer, demonstration, case study, and problem solving methods and techniques, and 3) rarely employed student centered discussion, laboratory practice, role playing and project-based learning methods in their classroom. Consequently, there exist some differences between theory and practice regarding teaching methods and techniques of teachers in this study.
\end{abstract}

Keywords: science education, teaching methods and techniques, teacher

\section{Extended Abstract}

Purpose and Significance: The purpose of this present study is to determine the methods and techniques that science teachers mostly employ in their classroom settings. The differences between theory and practice regarding science teachers' teaching methods and techniques have been investigated by the researchers in this study. By doing so, the researchers argue that this study might help shedding light on how much teachers are prepared for real life classroom situations and how often they employ different teaching methods and techniques when they are teaching. In order to reach the purpose of this current study, the researchers have attempted to address the following research questions:

1) What do science teachers know about teaching methods and techniques?

2) How often do science teachers employ teaching methods and techniques in their classroom settings?

3) What do science teachers prefer the main teaching methods and techniques? and

4) What are the most effective teaching methods and techniques for science teaching in students' perception?

Methods: In order to settle the sample of this study, the researchers have used two steps. First, the researchers have randomly selected 17 middle schools among all middle

\footnotetext{
${ }^{*}$ Corresponding Author: Assoc. Prof. Dr., Amasya University, Amasya, Turkey, orseka@yahoo.com

** Assist. Prof. Dr., Amasya University, Amasya, Turkey, adembayar80@ gmail.com

**** Teacher, Ministry of National Education, Saftekin Gazi Middle School, Mus, Turkey, mertkaya0548@ gmail.com
} 
schools in Amasya, Turkey. Second, the researchers have determined 81 teachers who have been working as science teachers in these selected 17 middle schools. After that, these teachers have been purposefully invited by the researchers for participation in survey implementation. However, 60 of these invited 81 teachers have voluntarily participated in survey. Then, the researchers have randomly selected 6 teachers (out of 60) voluntarily participated in survey to observe them in real classroom situations. The observation process has lasted 6 times during the study. In addition, the researchers have invited 154 students, who have been taught by the selected 6 teachers in this study, for focus group interviewing. The researchers employed semi structured interview protocol with these 154 students. 54 of these participants are $6^{\text {th }}$ grades, 52 of them are $7^{\text {th }}$ grades, and 48 of them are $8^{\text {th }}$ grades. The researchers have divided these selected students to some subgroups. They are 1) $6^{\text {th }}$ grade students to 6 groups (9 students for each group), 2) $7^{\text {th }}$ grade students to 6 groups ( 8 students for 4 groups and 10 students for 2 groups), and 3) $8^{\text {th }}$ grade students to 6 groups ( 8 students for each group). Totally, the researchers have come together with students for 18 focus group interviews. Each interview has lasted around 50 minutes. All interviews were recorded and transcribed word by word.

Results: After analyzing the collected data, the researchers have come to recognize that science teachers in this study are more likely using narrative method when they teach in their real life classroom situations. In addition, the researchers have found that teachers in this study support their teaching by the following teaching methods and techniques:1) question and answer, 2) demonstration, 3) case study, and 4) problem solving. The researchers have additionally come to know that teachers in this study rarely employ the following teaching methods and techniques when they are teaching in real life classroom environment: 1) student centered discussion, 2) laboratory practice, 3) role playing, and 4) project-based learning.

Discussion and Conclusions: After interpretation the findings of this present study, the researchers have come to the conclusion that there exist some differences between theory and practice regarding teaching methods and techniques of science teachers in this study. In this context, the quality of teachers' preparedness, as one of the most important components of teaching process, should have been questioned by researchers, educators, and policy makers not only in Turkey but also all countries in the world. Since, there is an agreement among researchers that teacher quality either positively or negatively affect learning of students; as a result, the achievement of students. If teachers are prepared well in their pre-service education programs, there is still another important question for providing efficient opportunities to students. This is if teachers are prepared well in their pre-service education programs, why they prefer to employ just some limited, in other words traditional, teaching methods and techniques such as narrative method, question and answer, demonstration, case study, and problem solving rather than reform-based, in other words nontraditional, teaching methods and 
techniques such as student centered discussion, laboratory practice, role playing, and project-based learning. That is why, the researchers should focus on the reasons of why teachers are mostly like to use just some defined teaching methods and techniques even though the benefits of the variety of teaching methods and techniques have been accepted by international researchers for effective teaching and more importantly for permanent learning. 


\section{Fen Bilimleri Öğretmenlerinin Kullandıkları Öğretim Yöntem ve Teknikleri Üzerine Bir Araştırma: Amasya Örneği}

\author{
Orhan KARAMUSTAFAOĞLU*
}

\author{
Adem BAYAR ${ }^{* *}$
}

$\operatorname{Mert~KAYA~}^{* * *}$

Makale Gönderme Tarihi: 28 Mart 2014

Makale Kabul Tarihi: 18 Temmuz 2014

ÖZET: Bu çalışmanın amacı, fen bilimleri dersi öğretmenlerinin hangi öğretim yöntem ve tekniklerini derslerinde daha ağırlıklı olarak kullandıklarını belirlemektir. Özel durum çalışması kullanılarak gerçekleştirilen bu çalışmada araştırmacılar çalışma için veri toplamak amacıyla araştırma sürecinde çalışmaya gönüllü olarak katılan 60 fen bilgisi öğretmenine anket uygulamışlardır. Bunun devamında ise araştırmacılar ankete katılan 60 öğretmenden 6 tanesi rastgele seçerek çalışmanın amacına yönelik gözlem yapmış ve çalışmaya katılan bu öğretmenlerin derslerine girdikleri 154 öğrenciyle görüşmeler gerçekleştirmişlerdir. Çalışma sonucunda, araştırmacılar çalışmaya katılan öğretmenlerinin genel olarak anlatım yöntemini kullanmayı daha çok tercih ettiklerini ve bu yöntemi soru-cevap, gösteri ve örnek olay yöntemi ve problem çözme yöntemleri ile destekledikleri sonucuna ulaşmışladır. Ayrıca, çalışmaya katılan öğretmenlerin öğrenci merkezli tartışma, laboratuar, rol oynama ve proje temelli öğrenme yöntemlerini daha az tercih ettikleri sonucuna ulaşılmıştır. Bu çalışmanın sonucunda araştırmacılar özetle bu çalışmaya katılan öğretmenlerin öğretim yöntem ve teknikleri kullanımında teori ve uygulama açısından bazı farkları olduğu sonucuna ulaşmışlardır.

Anahtar sözcükler: Fen eğitimi, öğretim yöntem ve teknikleri, öğretmen.

\section{Giriş}

Eğitim literatüründe birçok tanımı günümüze değin yapılmış olmasına karşın genel kabul görmüş olarak eğitim, bireyin davranışlarında kendi yaşantısı yoluyla istenen yönde davranış değişikliği meydana getirme süreci olarak tanımlanmaktadır (Ertürk, 1972). Bu bağlamda okulda formal olarak sunulan eğitimi, önceden belirlenmiş ve planlanmış öğretim yöntemleri ile hedeflere yönelik davranış kazandırma süreci olarak tanımlayabiliriz. Fen bilimlerinin yaşamımızdaki etkisinin farkındalığında olduğumuz günümüzde, fen eğitiminin önemi birçok araştırmacı tarafından kabul edilen bir gerçektir (Ayas, Çepni, Akdeniz, Özmen, Yiğit ve Ayvacı, 2005). Birbir ve Salan (1999)'a göre fen eğitiminin amacı, öğrencilerin fen kavramlarını anlamlı ve kalıcı bir şekilde öğrenmelerini sağlamak, bunun yanında düşünme yeteneklerini de geliştirmektir (akt. Doğru ve Aydoğdu, 2003). Ayrıca bu eğitim kapsamında gerçekleştirilen öğretimlerle, öğrencilerin araştıran-sorgulayan, etkili kararlar verebilen, problem çözebilen, kendine güvenen, işbirliğine açık, etkili iletişim kurabilen, sürdürülebilir kalkınma bilinciyle yaşam boyu öğrenen bireyler olarak yetişmeleri amaçlanmaktadır (MEB, 2013).

Son yıllarda fen eğitimi ve öğretiminde 'fen okuryazarı' kavramı üzerine yoğunlaşmış olduğu görülmektedir. Fen okuryazarı denildiğinde; bilgiyi ezberleyen değil bilgiye ulaşan, ulaştı̆̆ bilgiyi farklı ve gereken durumlarda kullanabilen fennin teknoloji ve toplumla etkileşiminin bilincinde olan bireyler akla gelir (Solmaz, 2007).

\footnotetext{
* Sorumlu Yazar: Doç. Dr., Amasya Üniversitesi, Amasya, orseka@yahoo.com

** Yrd. Doç. Dr., Amasya Üniversitesi, Amasya, adembayar80@gmail.com

Öğretmen, Saftekin Gazi Orta Okulu, Muş, mertkaya0548@gmail.com
} 
Yenilenen fen bilimleri öğretim programında, fen okuryazarı bireyler; fen bilimlerine ilişkin bilgi, beceri, olumlu tutum, algl ve değere; fen bilimlerinin teknoloji-toplumçevre ile olan ilişkisine yönelik anlayışa ve psikomotor becerilere sahiptir şeklinde tanımlanmaktadır (MEB, 2013). Bireylerin fen okuryazarı olarak yetişmesinde öğretmenin öğretim ortamındaki verimliliği oldukça önemli olduğu günümüz dünyasında tartışılmayacak derecede kabul görülmüş bir düşüncedir. $\mathrm{Bu}$ nedenle eğitimin temel taşı olan öğretmenin sahip olması gereken yeterlilikler eğitimin kalitesini doğrudan etkilemektedir (Tutkun, Koç, Sezer ve Polat, 2004).

Çepni, Ayas, Johnson ve Turgut 1997 yılında fen bilimleri öğretmenlerinin yeterliklerini saptamaya yönelik olarak yaptıkları çalışmada, öğretmenlerin yeterliklerini;

1) Konuyu tam bilmek

2) Öğretme yeteneği

a) planlama ve hazırlık

b) öğretim yöntem ve tekniklerini kullanma

c) etkili iletişim kullanarak ve dersin düzenini gerekli dikkati kullanarak dersi düzenleme

d) hedefleri belirleme ve değerlendirme

3) Sınıf yönetimi ve öğrencilerle ilişkiler

4) Öğrenci rehberlik hizmetlerine yönelik ilişkin rolleri belirleme

5) Kişisel ve mesleki yeterlilikler olarak belirlemişlerdir.

Çepni ve diğ. (1997) yaptıkları bu çalışmanın bulgularının göstermiş olduğu gibi öğretmenin öğretme yeteneği kapsamında ele alınan öğretim yöntem ve teknikleri öğretimin etkililiği açısından önemli bir yere sahiptir. Bu anlamda öğretim yöntem ve tekniği ile ilgili literatürde birçok tanımlama yapılmıştır. Örneğin, Korkmaz (2002)'a göre çağdaş fen bilgisi ders programlarında yöntem, bilimsel tutumların ve zihinsel süreç becerileri kullanım yolu ile bilimsel kavram ve ilkelere varma olarak ifade edilmiştir. Alaylıoğlu ve Oğuzkan (1974)'a göre yöntem ise, "Bir sorunu çözmek bir deneyi sonuçlandırmak, bir konuyu öğrenmek ya da öğretmek gibi amaçlara ulaşmak için bilinçli olarak seçilen ve izlenen düzenli yoldur”. Öğretim yöntemi ise, “Öğrencilerin özellikleri ders araç gereçleri ile tüm öğrenme durumu göz önünde tutularak saptanan ve izlenen mantıklı yol” olarak tanımlanmaktadır (akt. İlhan, 2006). Öğretim tekniği ise, "Bir öğretme yöntemini uygulamaya koyma biçimidir" (Demirel, 2003, s. 153).

Öğretmenin öğretim etkinliklerini düzenlerken kullandığı yöntem; öğretim stratejisinden öğretim yöntemlerine, öğretim yöntemlerinden öğretim etkinliklerine ve öğretmenin kullandığı özgün tekniklere uzanmaktadır (Erginer, 2000). Öğretmenler farklı yöntemler kullanmak suretiyle öğrencinin anlama yeteneğinin gelişmesine ve derinleşmesine katkı sağlamaktadırlar. Bu yetenekleri geliştirilmiş öğrencilerin iletişim 
gücünün arttığı ve yeni etkinlikler üretebildikleri iddia edilmektedir (Young ve Kellogg, 1993). Dolayısıyla, öğretmenin yürüttüğü derslerde seçeceği öğretim yöntem ve tekniklerinin, konuların içeriğine, öğrencilerin yaşlarına, ön öğrenmelerine, ilgilerine uygun olmalı ve onları yaratıcı düşünmeye, araştırmaya yönlendirmelidir.

Eğitim öğretim etkinliklerin de kullanılan birçok öğretim yöntem ve tekniği bulunmakta olup bunlardan bazıları aşağıda verilmiştir:

1. Anlatım Yöntemi: Öğretmenlerin sahip oldukları bilgileri öğrencilerine mantıklı bir düzende, çok zaman harcamadan sözlü olarak ifade etmeye çalıştıkları geleneksel bir öğretim yöntemidir. Anlatım yöntemi, öğretmen merkezli olup, daha çok sunuş yolu ile öğretme yaklaşımında ve bilgi düzeyindeki davranışların kazandırılmasında kullanılır (Kaptan, 1999).

2. Soru-Cevap Yöntemi: Temeli Sokrates'in öğretisine dayanan bu yöntem, öğrencilere düşünme ve konuşma alışkanlıklarının kazandırılmasında oldukça önemlidir ve her dersin öğretiminde kullanılabilir. Bu yöntem etkili kullanılırsa öğrencileri eleştirel düşünmeye sevk eder. Fen bilgisi dersinin amaçlarından biri öğrencileri eleştirici düşünceye sevk etmektir (Kaptan, 1999).

3. Gösteri Yöntemi: Gösteri, öğretmenin veya öğrenci gruplarının herhangi bir konuyu laboratuarda, sınıfta veya diğer öğrencilerin önünde deneyerek, araç ve gereçler kullanarak açıklamaları veya sunmalarıdır (Hesapçığlu, 1998).

4. Örnek Olay Yöntemi: Örnek olay inceleme yöntemi, gerçek hayattan alınmış veya karşılaşılması olası olan bir problemin sınıf ortamında derinlemesine çalışılmasıdır. Seçilen örnek olay genel bir problemi ya da konuyu temsil etme gücüne sahip değilse, örnek benzer olaylara genellenemeyecektir (Tan, 2007).

5. Problem Çözme Yöntemi: Problem, önceden öğrenilmiş teorem ya da kurallar yardımıyla çözümü istenen bir soru olarak tanımlanabilir. Problem çözümü için tek bir yol değil, en iyi bir yol vardır. Problem çözme, amaca ulaşabilmek için alternatifler arasından en uygununu belirlemektir (Taşpınar, 2007). Problem çözme yönteminde Benjamin Bloom'un taksonomisinin üst basamamağında yer alan analiz etme ve sentez etme gibi yüksek bilişsel fonksiyonları kullanılmaktadır.

6. Laboratuvar Yöntemi: Kuramsal bilgilerin laboratuarda öğrenciler tarafından yapılan deneylerle öğrenilmesine dayalı yöntemdir. $\mathrm{Bu}$ yöntemle öğrenciler, laboratuvardaki araç-gereç ve malzemelerle öğretmenin gözetim ve denetiminde deneyler yaparak fen konularına ilişkin davranışlar kazanırlar. $\mathrm{Bu}$ yöntemle öğretimin maliyeti, sunumu gerektiren yöntemlere göre daha yüksektir (Karamustafaoğlu ve Yaman, 2014).

7. Proje Yöntemi: Daha fazla bilgi edinmek istenilen bir konu hakkında derinlemesine araştırma yapmak ve bir ürün ortaya koymak için 
uygulanan bir yöntemdir. Proje yönteminde öğrenciler, inceledikleri konularla ilgili ilk elden, yaparak, yaşayarak, inceleyerek bilgi kazanırlar (Kaptan ve Korkmaz, 2002).

8. Gezi-Gözlem Yöntemi: Eğitsel amaçları gerçekleştirmek için okul tarafından organize edilen gezi ve bu geziye ilişkin tüm etkinlikler gezigözlem gezisi yöntemi kapsamındadır (Küçükahmet, 2005).

Yenilenen Fen Bilimleri Dersi Öğretim Programı'nda öğrencilerin fen bilimleri alanındaki bilgiyi anlamlı öğrenebilmeleri için derslerin uygulanmasında öğrencinin aktif, öğretmenin ise yönlendirici olabileceği problem, proje, argümantasyon, işbirliğine dayalı gibi yöntemler benimsenmiştir (MEB, 2013).

\section{Çalıșmanın Amacı ve Araștırma Soruları}

Yukarıda kısaca anlatılan öğretim yöntemlerinin eğitim-öğretim ortamlarında uygulanmasına ilişkin olarak her birisinin ayrı ayrı avantajları ve dezavantajları bulunmaktadır. Bu bağlamda, birinin diğerine üstünlüğü ya da diğerlerinden daha iyi olduğunu ifade etmek olanaksızdır. Bunun yerine öğretmen, sınıfına en uygun öğretim yöntemini seçmeli ve sınıftan aldığı işaretlere göre gerek duyması halinde değişikliklere gitmelidir (Küçükahmet, 1997). Öğretmenin dersini yürütürken, öğrencilerin derse dikkatlerini çekmesi, aktif olarak onları derse katması, öğrenme ortamının daha etkileyici olması ve öğrenmelerin hem eğlenceli hem de kalıcı olabilmesi için kullanması uygun ve gerekli olan yöntemleri tespit etmesi önemlidir (Erdem, 1997). Bu bağlamda, öğretmenin öğretim sürecinde öğretim yöntem ve teknikleri konusunda istenilir nitelikte bilgiye sahip olması ve bu bilgileri uygulaması gerçeğini ön plana çıkmaktadır. Ayrıca, öğretmenlerin ders sürecinde hangi öğretim yöntem ve tekniklerinden faydalandıkları konusunda bir literatür incelemesi yapıldığında; genellikle ilk ve ortaöğretim okullarındaki öğretmenlerin kullandıkları yöntemlerin araştırıldığı ya da sadece öğrenci görüşlerine dayalı olarak öğretim elemanlarının kullandıkları yöntemlerin tespitinin gerçekleştirildiği anlaşılmıştır.

Belirtilen gerçek ve gerekçelerden ten yola çıkarak bu çalışmanın amacını; Amasya ili merkez ortaokullarında Fen bilimleri öğretmeni olarak görev yapmakta olan öğretmenlerin, hangi tür öğretim yöntem ve teknikleri derslerinde daha ağırlıklı olarak kullandıklarını tespit etmek olarak açıklayabiliriz. Bu amaca ulaşmak için araştırmacılar bu çalışmada aşağıdaki sorulara yanıt aramışlardır:

1. Fen bilimleri öğretmenlerinin öğretim yöntem ve teknikleri hakkında bilgi düzeyleri nedir?

2. Fen bilimleri öğretmenlerinin öğretim yöntem ve tekniklerini kullanma sıklıkları nedir?

3. Fen bilimleri öğretmenlerinin tercih ettikleri başlıca öğretim yöntem ve teknikleri nedir?

Öğrencilerin fen derslerinin yürütülmesinde kullanılmasını istedikleri öğretim yöntemleri nedir? 


\section{Yöntem}

$\mathrm{Bu}$ çalışma, sınırları belirlenen bir konu dâhilinde derinlemesine araştırma yapabilme olanağı sağlayan özel durum yaklaşımı kapsamında gerçekleştirilmiştir. Bu yöntem, çeşitli tekniklerle elde edilen verilerin sebep-sonuç ve değişkenlerini karşılıklı ilişkileri cinsinden açıklayabilmeye olanak sağlar (Cohen ve Manion, 1994; Merriam, 1988; Yin, 2009).

Araştırmacılar çalışmanın örneklemini belirlemek için iki kademeli bir yol izlemişlerdir. Bunun için önce Amasya ilindeki ortaokullar arasından rastgele olarak 17 ortaokul seçilmiştir. Sonra, bu seçilen okullarda görev yapmakta olan 81 Fen Bilimleri dersi öğretmeninin tamamı ankete katılmak için çalışmaya davet edilmişlerdir. Ancak davet edilen bu öğretmenlerden 60 tanesi ankete gönüllü olarak katılmışlardır. Yarısı erkek olan katılımcı öğretmenlere ait demografik bilgiler Tablo 1'de sunulmuştur. Ankete katılan öğretmenlerden rastgele seçilen ve katılımcıların \%10'u olan 6 öğretmenin dersleri altışar saat olarak araştırmacılar tarafından gözlemlenmiştir. Son olarak gözlem yapılan bu 6 öğretmenin 6. 7. ve 8. sinıflarda bulunan 154 öğrencisiyle guruplar halinde yarı yapılandırılmış görüşmeler gerçekleştirilmiştir. Grup mülakatların gerçekleştirilmesinin en önemli gerekçeleri, öğrencilerin mülakatlar sürecinde belirtmeyi unutabilecekleri konuların arkadaşlarının ifadelerinden yararlanarak hatırlamalarını ve zamandan tasarruf sağlamaktır.

\section{Veri Toplama Araçları}

Fen bilimleri öğretmenlerin öğretim yöntem ve tekniklerle ilgili sahip oldukları bilgi düzeyi ve bu yöntem ve teknikleri kullanma sıklıkları Bulut (2010) tarafından geliştirilen anketin uygulanması ile incelenmiştir. Anket; öğretmenlerin öğretim yöntem ve tekniklerde sahip oldukları bilgi düzeyleri ve kullanma sıklıklarını, yöntem ve tekniklere yardımcı olan araç-gereç yeterliliğini, yöntem ve teknikleri belirlemek amacı ile üç bölümden oluşmuştur. Birinci bölüm, öğretmenlere ait demografik bilgilerden oluşmaktadır. Anketin ikinci bölümü öğretim yöntem ve teknikler konusunda sahip oldukları bilgi düzeyleri, bu yöntem teknikleri kullanma sıklıkları, fen bilimleri öğretimi açısından en etkili gördükleri üç yöntem ve bu yöntem teknikleri kullanıp kullanmama gerekçelerini ifade etmelerini içeren sorulardan oluşmaktadır. Anketin üçüncü bölümünde ise laboratuarın varlığı, araç-gereç yeterliliği, laboratuarı kullanma sıklığ ve yöntem ve tekniklere yönelik diğer görüşleri sorulmuştur. Çalışma öncesinde uygulanacak olan bu anketle ilgili olarak 3 alan eğitimcisi öğretim üyesi ve 3 öğretmenden uzman görüşleri alınarak anketin geçerliliği tartışılarak bu çalışmada kullanılmasının uygun olduğuna karar verilmiştir. İlgili anketin güvenirliğini ölçmek amaciyla uygulanan SPSS programı sonucunda Crombach Alpha değeri 0.90 olarak bulunmuştur (Bulut, 2010). Yürütülen bu çalışmada ise Crombach Alpha değeri 0.72 olarak hesaplanmıştır. Bu araştırmada öğretmenlerin kişisel bilgileri, en etkili üç yöntem ve yöntem teknikleri kullanma ve kullanmama gerekçeleri ve laboratuar varlığı, kullanma sıklığı ve araç-gereç yeterliliği belirlenirken frekans (f) ve yüzde (\%) kullanılmıştır. 
Ayrıca, öğretmenlerin ankette belirttikleri bulgular ile derste kullandıkları öğretim yöntem ve tekniklerinin paralelliğini incelemek üzere ankete benzer içerikte araştırmacılar tarafından yarı yapılandırılmış bir gözlem formu geliştirilmiştir. Bu formun hazırlanmasında iki fen bilgisi öğretmeninin öneri ve görüşleri göz önünde bulundurulmuş fen eğitimi ve eğitim bilimleri alanında uzman olan iki öğretim üyesiyle çalışmanın amacına ilişkin kritik edilmiştir. Bu kapsamda çalışmaya gönüllü olarak katılan 60 öğretmenden rastgele seçilen 6 öğretmenin 2013-2014 eğitim-öğretim yıl1 güz yarıyılında 6 saat boyunca dersleri katılımsız gözlemlerle izlenmiş ve bu süreç içerisinde kendilerine ait ders içi faaliyetleri gözlem formuna düzenli olarak gözlem formlarına kaydedilmiştir.

Bununla birlikte öğrencilerle yapılan odak gurup mülakatlar ile öğrencilerden öğretmenlerinin dersi işleme şekli ve daha etkili öğrenmeleri için neler olması gerektiği düşüncesine yönelik görüşler altı adet açık uçlu sorudan oluşan mülakat protokolü ile alınmıştır. 154 öğrenciyle yapılan mülakatlar yarı yapılandırılmış olarak gerçekleştirilmiştir. Mülakat grubunda bulunan 154 öğrenciden 54'ü 6. sınıf, 52'si 7. sınıf, 48'i 8. sınıf öğrencisidir. Mülakat 6. sınıf öğrencilerine 9 kişilik gruplarla 6 oturum, 7. sınıf öğrencilerine 8 kişilik grupla 4 ve 10 kişilik grupla 2 oturumdan oluşan toplam 6 oturum, 8. sınıf öğrencilerine 8 kişilik gruplarla 6 oturum olmak üzere toplam 18 oturumda sürdürülmüştür.

Bu çalışma Amasya ili kapsamındaki 17 ortaokulda görev yapan 60 fen bilimleri öğretmeni ile sınırlandırılmıştır.

\section{Verilerin Analizi}

Fen bilimleri öğretmenlerinin öğretim yöntem ve teknikleri hakkında bilgi düzeylerinin ve yürüttükleri derslerde hangi yöntemleri ne sıklıkla kullandıklarını belirlemek amaciyla amaciyla kendilerine uygulanan anketten elde edilen veriler frekans, yüzde değerleri kullanılarak analiz edilmiştir. Yarı-yapılandırılmış gözlem formunun nicel kısmından elde edilen veriler de, öğretmenlerin bir ders sürecinde hangi yöntemlere yer verdiklerinin nasıl bir dağılım gösterdiğinin tespiti için aynı şekilde frekans ve yüzde dağılımı hesaplanmıştır.

Gözlem formunun nitel kısmı ve mülakat verilerinin analizinde ise içerik analizi yönteminden faydalanılmıştır. İçerik analizi, belirli kurallara dayalı kodlamalarla, bir metnin bazı sözcüklerinin daha küçük içerik kategorileri ile özetlendiği sistematik, yinelenebilir bir tekniktir (Büyüköztürk, Kılıç Çakmak, Akgün, Karadeniz ve Demirel, 2008). Ders gözlemlerinden sağlanan nitel veriler irdelenerek anket verilerinin karşılaştırlması ile analiz edilmiştir. Mülakatlardan elde edilen ham veriler kodlama yapılarak okuyucular için anlamlı bir hale getirilmiştir. Kodlamalar işlemi araştırmacılardan biri tarafindan tekrarlı olarak yapılmış, böylece araştırmanın amacına bağlı kalınarak, gereksiz kodlamalar çıkarılmıştır. Sonuç olarak görüşme verileri, ortaklaşa verilen ve çok az sayıda öğrencinin ya da tek bir öğrencinin vurgulamasına rağmen ilgi çekici olanlara değinilerek soru-cevap formatında sunularak analiz edilmiştir. 


\section{Bulgular}

Bu bölüm anket, gözlem ve mülakatlardan elde edilen bulgular olmak üzere üç alt başlık halinde sunulmuştur.

\section{Anket Verilerinden Elde Edilen Bulgular}

Tablo 1

Araştırmaya Katılan Öğretmenlerin Demografik Bilgileri $(n=60)$

Özellikler

f $\%$

Cinsiyet

- Kadın

$30 \quad 50$

- Erkek

$30 \quad 50$

Mezun Olunan Okul Türü

- Eğitim Fakültesi

$20 \quad 33.3$

- Fen-Edebiyat Fakültesi

$\begin{array}{ll}40 & 66.7\end{array}$

Mesleki Hizmet Süresi

- 6-10 y1l

$10 \quad 16.6$

- 11-15 y1

$10 \quad 16.6$

- 16-20 y1

$30 \quad 50.2$

- 21 yıl ve üstü

$10 \quad 16.6$

Hizmet İçi Eğitim Alma Durumu

- Evet

- Hayır

10

16.7

Tablo 1 incelendiğinde, ankete katılan öğretmenlerin yarısının erkek, 1/3'ünün eğitim fakültesi mezunu, yaklaşı 3/4'ünün öğretmenlik deneyiminin 15 yıldan fazla olduğu ve büyük çoğunluğunun meslekte hizmet-içi eğitim aldığı görülmektedir.

Tablo 2

Fen Bilimleri Öğretmenlerinin Öğretim Yöntem ve Teknikleri Konusunda Sahip 
Oldukları Bilgi Düzeyi $(n=60)$

\begin{tabular}{|c|c|c|c|c|c|c|c|c|c|c|}
\hline \multirow{3}{*}{ Yöntem ve Teknikler } & \multicolumn{10}{|c|}{ Bilgi Düzeyi } \\
\hline & \multicolumn{2}{|c|}{ Hiç } & \multicolumn{2}{|c|}{$\mathbf{A z}$} & \multicolumn{2}{|c|}{ Orta } & \multicolumn{2}{|c|}{ İyi } & \multicolumn{2}{|c|}{ Çok İyi } \\
\hline & $f$ & $(\%)$ & $f$ & $(\%)$ & $f$ & $(\%)$ & $f$ & $(\%)$ & $f$ & $(\%)$ \\
\hline Anlatım (Takrir) & - & - & - & - & - & - & 50 & 83.3 & 10 & 16.7 \\
\hline Soru-Cevap & - & - & - & - & - & - & 30 & 50 & 30 & 50 \\
\hline Problem Çözme & - & - & - & - & - & - & 60 & 100 & - & - \\
\hline Gösterip Yaptırma & - & - & - & - & 10 & 16.7 & 50 & 83.3 & - & - \\
\hline Örnek Olay & - & - & - & - & - & - & 50 & 83.3 & 10 & 16.7 \\
\hline Gezi-Gözlem & - & - & 20 & 33.3 & 10 & 16.7 & 30 & 50 & - & - \\
\hline Rol Oynama & - & - & 10 & 16.7 & 10 & 16.7 & 40 & 66.6 & - & - \\
\hline Benzetim & - & - & - & - & - & - & 60 & 100 & - & - \\
\hline Laboratuar & - & - & - & - & 10 & 16.7 & 40 & 66.6 & 10 & 16.7 \\
\hline Proje & - & - & - & - & 20 & 33.3 & 40 & 66.7 & - & - \\
\hline Drama & 10 & 16.7 & - & - & 20 & 33.3 & 30 & 50 & - & - \\
\hline Kavram Haritas1 & - & - & - & - & 10 & 16.7 & 40 & 66.6 & 10 & 16.7 \\
\hline Münazara & 10 & 16.7 & 10 & 16.7 & - & & 40 & 66.6 & - & - \\
\hline Beyin Fırtınası & - & - & 10 & 16.7 & - & - & 40 & 66.6 & 10 & 16.7 \\
\hline Zit Panel & - & - & - & - & 30 & 50 & 30 & 50 & - & - \\
\hline Sempozyum & - & - & - & - & 10 & 16.7 & 50 & 83.3 & - & - \\
\hline Çember Tekniği & - & - & 10 & 16.7 & 30 & 50 & 20 & 33.3 & - & - \\
\hline Altı Şapkalı Düşünme Tekniği & - & - & - & - & - & - & 50 & 83.3 & 10 & 16.7 \\
\hline Forum & - & - & - & - & 20 & 33.3 & 40 & 66.7 & - & - \\
\hline Tartışma Tekniği & - & - & - & - & 10 & 16.7 & 50 & 83.3 & - & - \\
\hline Mikro Öğretim & - & - & 10 & 16.7 & 30 & 50 & 20 & 33.3 & - & - \\
\hline İşbirlikli Öğrenme & - & - & - & - & - & - & 40 & 66.7 & 20 & 33.3 \\
\hline
\end{tabular}

Araştırmaya katılan fen bilimleri öğretmenlerinin öğretim yöntem ve teknikler konusunda sahip oldukları bilgi düzeyleri Tablo 2'de verilmiştir. Fen bilimleri öğretmenlerinin \%50'sinin soru cevap yöntemi ile ilgili çok iyi bilgi sahibi olduğu, buna karşın münazara ve drama yöntemlerinde ise \%16.7'sinin hiç bilgi sahibi olmadığ1 görülmüştür.

Çalışmaya katılan fen bilimleri öğretmenlerinden \%83.3'ünün anlatım yönteminde iyi, diğer \%16.7'sinin ise çok iyi bilgi düzeyine sahip olduklarını belirtmişlerdir. Çalışmaya katılan öğretmenlerin \%100'ü problem çözme yöntemini iyi düzeyde bilgi sahibi olduklarını, gösterip yaptırma yöntemine ilişkin ise \%16.7'si orta, 
\%83.3'ü iyi bilgi sahibi oldukların belirtmişlerdir. Ayrıca, öğretmenlerin \%83.3’ü örnek olay yöntemi hakkında iyi derecede, \%16.7'si ise örnek olay yöntemi konusunda çok iyi bilgi sahibi olduklarını belirtmişlerdir.

Öğretmenlerinin gezi-gözlem yöntemi hakkında ise \%33.3'ü az, \%16.7'si orta, \%50' si iyi düzeyde yöntem hakkında bilgi sahibi oldukları, öğretmenlerinin rol oynama yöntemi hakkında \%16.7'sinin az, \%16.7'sinin orta, \%66.6'sının iyi derecede bilgi sahibi oldukları görülmüştür. Çalışmaya katılan öğretmenlerin \%100’ü benzetim yöntemi konusunda iyi bilgi sahibi olduklarını belirtirlerken laboratuar yönteminde \%16.7'si orta, \%66.6'sı iyi, \%16.7'si çok iyi düzeyde bilgi sahibi olduklarını ifade etmişlerdir.

Tablo 3

Fen bilimleri Öğretmenlerinin Öğretim Yöntem ve Tekniklerini Kullanma Sıklı̆g $(n=60)$ 


\begin{tabular}{|c|c|c|c|c|c|c|c|c|c|c|}
\hline \multirow{3}{*}{ Yöntem ve Teknikler } & \multicolumn{10}{|c|}{ Kullanma Sıklığı } \\
\hline & \multicolumn{2}{|c|}{$\begin{array}{l}\text { Hiçbir } \\
\text { zaman }\end{array}$} & \multicolumn{2}{|c|}{$\begin{array}{c}\text { Çok } \\
\text { seyrek }\end{array}$} & \multicolumn{2}{|c|}{ Bazen } & \multicolumn{2}{|c|}{$\begin{array}{l}\text { Çoğu } \\
\text { Zaman }\end{array}$} & \multicolumn{2}{|c|}{$\begin{array}{c}\text { Her } \\
\text { Zaman }\end{array}$} \\
\hline & $f$ & $(\%)$ & $f$ & $(\%)$ & $f$ & $(\%)$ & $f$ & $(\%)$ & $f$ & $(\%)$ \\
\hline Anlatım(Takrir) & - & - & 10 & 16.7 & 20 & 33.3 & 30 & 50 & - & - \\
\hline Soru-Cevap & - & - & - & - & - & - & 50 & 83.3 & 10 & 16.7 \\
\hline Problem Çözme & - & - & - & - & 20 & 33.3 & 40 & 66.7 & - & - \\
\hline Gösterip Yaptırma & - & - & - & - & 20 & 33.3 & 40 & 66.7 & - & - \\
\hline Örnek Olay & - & - & - & - & 20 & 33.3 & 20 & 33.3 & 20 & 33.3 \\
\hline Gezi-Gözlem & - & - & 60 & 100 & - & - & - & - & - & - \\
\hline Rol Oynama & - & - & 20 & 33.3 & 20 & 33.3 & 20 & 33.3 & - & - \\
\hline Benzetim & - & - & - & - & - & - & 60 & 100 & - & - \\
\hline Laboratuar & - & - & - & - & 20 & 33.3 & 30 & 50 & 10 & 16.7 \\
\hline Proje & - & - & - & - & 40 & 66.7 & 20 & 33.3 & - & - \\
\hline Drama & 10 & 16.7 & - & - & 20 & 33.3 & 30 & 50 & - & - \\
\hline Kavram Haritas1 & - & - & - & - & 40 & 66.7 & 10 & 16.7 & 10 & 16.7 \\
\hline Münazara & 10 & 16.7 & 30 & 50 & 10 & 16.7 & 10 & 16.7 & - & - \\
\hline Beyin Firtınası & - & - & 30 & 50 & - & - & 20 & 33.3 & 10 & 16.7 \\
\hline Zit Panel & 10 & 16.7 & 40 & 66.7 & 10 & 16.7 & - & - & - & - \\
\hline Sempozyum & 10 & 16.7 & 40 & 66.7 & 10 & 16.7 & - & - & - & - \\
\hline Çember Tekniği & 30 & 50 & 20 & 33.3 & 10 & 16.7 & - & - & - & - \\
\hline Altı Şapkalı Düşünme Tekniği & - & - & 30 & 50 & 20 & 33.3 & 10 & 16.7 & - & - \\
\hline Forum & - & - & 60 & 100 & - & - & - & - & - & - \\
\hline Tartışma Tekniği & - & - & 10 & 16.7 & 10 & 16.7 & 40 & 66.7 & - & - \\
\hline Mikro Öğretim & 20 & 33.3 & 30 & 50 & 10 & 16.7 & - & - & - & - \\
\hline İşbirlikli Öğrenme & - & - & 10 & 16.7 & 20 & 33.3 & 20 & 33.3 & 10 & 16.7 \\
\hline
\end{tabular}

Araştırmaya katılan öğretmenlerinin öğretim yöntem ve tekniklerini kullanma sıklığı Tablo 3'de verilmiştir. Tablo 3'e göre öğretmenlerin \%33.3'ünün örnek olay yöntemini her zaman kullandığı, buna karşın, \%50'sinin çember tekniğini hiçbir zaman kullanmadığı görülmektedir.

Tablo 3’te görüldüğü gibi, öğretmenlerinin \%83.3'ü soru-cevap yöntemini çoğu zaman ve \%16.7'si ise her zaman kullandıklarını, \%33.3'ü problem çözme yöntemini bazen, \%66.7'si çoğu zaman kullandıklarını belirtmişlerdir. Fen bilimleri öğretmenlerinin \%16.7'sinin anlatım yöntemini çok seyrek, \%33.3'nün bazen, \%50'si çoğu zaman kullandıklarını ifade etmişlerdir. Ayrıca öğretmenlerin \%33.3'ü gösterip yaptırma yöntemini bazen, \%66.7'si çoğu zaman kullandıklarını belirtirken, \%100'ü 
gezi-gözlem yöntemini çok seyrek kullandıklarını söylemişlerdir. Bunlara ek olarak, öğretmenlerin \%33.3'ü laboratuar yöntemini bazen, \%50'si çoğu zaman ve \%16.7'si ise her zaman kullandıklarını söylerlerken \%66.7'si kavram haritası yöntemini bazen, \%16.7'si çoğu zaman, \%16.7'si ise her zaman kullandıklarını belirtmişlerdir. Öğretmenlerin \%16.7'si münazara tekniğini hiçbir zaman, \%50'si çok seyrek, \%16.7'si bazen, \%16.7'si çoğu zaman kullandıklarını belirtirlerken bu öğretmenlerin \%100'ü benzetim yöntemini çoğu zaman kullandıklarını söylemişlerdir. Çalışmaya katılan öğretmenlerin \%16.7'si zit panel ve sempozyum tekniklerini hiçbir zaman, \%66.7'si çok seyrek , \%16.7'sinin bazen kullandıkları görülmüştür.

Tablo 4

Fen Bilimleri Öğretmenlerinin Fen Öğretiminde En Etkili Gördükleri Öğretim Yöntem ve Teknikleri $(n=60)$

\begin{tabular}{lcccccc}
\hline \multirow{2}{*}{ Yöntem ve Teknikler } & \multicolumn{3}{c}{ Tercih Sıralaması } & \\
& \multicolumn{2}{c}{$\mathbf{1 . Y o ̈ n t e m ~}$} & \multicolumn{2}{c}{ 2.Yöntem } & \multicolumn{2}{c}{ 3.Yöntem } \\
\cline { 2 - 7 } Anlatım & $f$ & $\boldsymbol{\%}$ & $\boldsymbol{f}$ & $\boldsymbol{\%}$ & $\boldsymbol{f}$ & $\mathbf{\%}$ \\
Soru-Cevap & - & - & 10 & 16.7 & - & - \\
Laboratuar & 10 & 16.7 & - & - & 20 & 33.4 \\
Gösterip Yaptırma & 10 & 16.7 & 10 & 16.7 & 20 & 33.4 \\
Proje & 10 & 16.7 & 20 & 33.4 & - & - \\
Problem Çözme & 10 & 16.7 & - & - & - & - \\
Beyin Fırtınası & - & & 10 & 16.7 & - & - \\
Benzetim & 10 & 16.7 & 10 & 16.7 & - & - \\
İşbirlikli Öğrenme & 10 & 16.7 & - & - & - & - \\
Gösteri & - & - & - & - & 10 & 16.7 \\
\hline
\end{tabular}

\section{Fen öğretiminde etkili birinci yöntem.}

Araştırmaya katılan fen bilimleri öğretmenlerinin seçtiği en etkili birinci yöntem Tablo 4'te gösterilmiştir.

Tablo 4 incelendiğinde öğretmenlerin 10’u (\%16.7) laboratuar yöntemini, 10’u (\%16.7) gösterip yaptırma, 10’u (\%16.7) soru-cevap yöntemini, 10’u (\%16.7) beyin firtınası, 10’u (\%16.7) proje yöntemini ve benzetim yöntemini ise yine 10 kişinin (\%16.7) seçtiği görülmektedir. Buna göre öğretmenler en etkili birinci yöntem olarak genel olarak farklı yöntemleri seçmişlerdir.

\section{Fen öğretiminde en etkili ikinci yöntem.}


Araştırmaya katılan öğretmenlerin seçtiği en etkili ikinci yöntem Tablo 4'te gösterilmiştir. Tablo incelendiğinde öğretmenlerin 10'u (\%16.7) laboratuar yöntemini, 20'si (\%33.4) gösterip yaptırma, 10’u (\%16.7) anlatım yöntemini, 10’u (\%16.7) beyin firtınası, 10’u (\%16.7) problem çözme yönteminin en etkili ikinci yöntem olduğunu belirtmiştir. Buna göre öğretmenlerin 20'si (\%33.4) en etkili ikinci yöntem olarak gösteri yaptırma yöntemini seçmiştir.

\section{Fen öğretiminde en etkili üçüncü yöntem.}

Araştırmaya katılan öğretmenlerinin seçtiği en etkili üçüncü yöntem Tablo 4'te gösterilmiştir. Tablo 4 incelendiğinde, öğretmenlerin 20'si (\%33.4) soru-cevap yöntemini, 20'si (\%33.4) laboratuar yöntemini, 10’u (\%16.7) işbirlikli öğrenmeyi ve 10 ’u (16.7) da gösteri yöntemini en etkili üçüncü yöntem olarak ifade etmiştir. Buna göre öğretmenlerin \%33.4'er olmak üzere en etkili üçüncü yöntem olarak soru cevap ve laboratuar yöntemlerini seçmiştir.

\section{Derslerin Gözlemlenmesiyle Elde Edilen Bulgular}

2013-2014 eğitim-öğretim yılı güz yarıyılında altı öğretmenin her birinin 6'şar saat boyunca dersleri izlenmiş ve ders içi faaliyetleri gözlem formuna kaydedilmiştir. $\mathrm{Bu}$ kapsamda, öğretmenlerin kullandıkları öğretim yöntemlerinin sıklıkları Tablo 5 'de verilmiştir.

\section{Tablo 5}

Öğretmenlerin bir ders sürecinde kullandıkları ögretim yöntemlerinin frekans ve yüzde dă̆ılımı $(n=6)$

\begin{tabular}{|c|c|c|c|c|c|c|c|c|c|c|c|c|c|c|c|c|}
\hline \multirow{3}{*}{$\begin{array}{l}\text { Yöntem } \\
\text { ve Teknikler }\end{array}$} & \multicolumn{16}{|c|}{ Dakikalar } \\
\hline & \multicolumn{2}{|c|}{5} & \multicolumn{2}{|c|}{10} & \multicolumn{2}{|c|}{15} & \multicolumn{2}{|c|}{20} & \multicolumn{2}{|c|}{25} & \multicolumn{2}{|c|}{30} & \multicolumn{2}{|c|}{35} & \multicolumn{2}{|c|}{40} \\
\hline & $f$ & $\%$ & $f$ & $\%$ & $f$ & $\%$ & $f$ & $\%$ & $f$ & $\%$ & $f$ & $\%$ & $f$ & $\%$ & $f$ & $\%$ \\
\hline Anlatım & 35 & 96 & 35 & 96 & 36 & 100 & 33 & 91 & 35 & 96 & 35 & 96 & 35 & 96 & 36 & 100 \\
\hline Soru-cevap & 18 & 50 & 21 & 58 & 20 & 54 & 24 & 66 & 18 & 50 & 22 & 60 & 21 & 58 & 14 & 38 \\
\hline Gösteri & 12 & 33 & 23 & 63 & 21 & 58 & 18 & 50 & 16 & 45 & 16 & 45 & 9 & 25 & 14 & 38 \\
\hline Örnek Olay & 3 & 8 & 7 & 20 & 9 & 25 & 16 & 45 & 15 & 41 & 14 & 38 & 14 & 38 & 6 & 16 \\
\hline Problem çözme & 12 & 33 & 9 & 25 & 9 & 25 & 6 & 16 & 5 & 13 & 3 & 8 & 9 & 25 & 12 & 33 \\
\hline Tartışma & - & - & - & - & - & - & 1 & 4 & 5 & 13 & 1 & 4 & 3 & 8 & - & - \\
\hline Laboratuar & - & - & - & - & - & - & - & - & - & - & 5 & 13 & 1 & 4 & - & - \\
\hline Rol oynama & - & - & - & - & - & - & 3 & 8 & 3 & 8 & - & - & - & - & - & - \\
\hline Proje & - & - & - & - & - & - & 3 & 8 & - & - & - & - & 6 & 16 & 7 & 20 \\
\hline
\end{tabular}

Tablo 5'te görüldüğg̈ gibi öğretmenlerin tamamı bir ders saati boyunca anlatım yöntemini 15. ve 40. dakikalarda kullanmıştır. Diğer dakikalarda ise anlatım yöntemini 
öğretmenlerin tamamına yakınının kullandıkları gözlemlenmiştir. Soru cevap yöntemini öğretmenler dersin başlangıcından 35. dakikasına kadar \%50-66 oranında yer verirken bu oran dersin son 5 dakikasında \%38'e düşmektedir. Öğrenci mülakatlarından da anlaşıldığ bir yerin bulunmayışı, araç ve gereç yetersizliği vb. durumlarda öğretmenler ders saatlerinde ağırlıklı olarak 10.ve 30. dakikalarda \%45-63 oranında gösteri yöntemini kullandığ1 gözlemlenmiştir. Öğretmenlerin günlük hayatta karşılaşılan problemleri sınıf ortamına taşıyarak öğrencilerden çözüm beklemesi ve konularla ilgili güncel yaşamdan örnekler sunarak tartışma ortamı hazırlaması en çok \%45 oranında 20. dakikada kullanırlarken bu oranın ilerleyen dakikalarda azaldığı tespit edilmiştir. Örneğin 6. sınıflarda derse giren bir öğretmenin Maddenin Tanecikli Yapısı ünitesinde fiziksel ve kimyasal değişim konusunu derste tartışırken öğrencilere "elma, armut gibi meyvelerin yenildikten sonra kalan kısımlarının renk değiştirmesi kimyasal değişime bir örnektir" şeklindeki ifadesi güncel yaşamla konuyu bağdaştırma adına gözlem verileri arasında yer almaktadır. Öğretmenler problem çözme yönteminden 5. dakikada \%33, 10., 15. ve 35. dakikalarda \%25 oranında yararlanmıştır. Tartışma, laboratuar, rol oynama, proje yöntemlerinin ise öğretmenlerce dersin 20. dakikasından itibaren çok az oranda kullandıkları gözlemlenmiştir.

Öğretmenler anlatım yöntemi kullanırken not tutturma ve önemli noktaları tahtaya yazmaya çoğunlukla her sınıfin ilk ünitelerinde bulunan hücre bölünmesi, vücudumuzdaki sistemler ve üreme, büyüme gibi biyoloji konularında çok sık başvurmuştur. Önceki konunun tekrar edilmesi ilk 15 dakikada olurken bu etkinlik 5. dakikadan 15. dakikaya doğru azalarak devam etmiştir. Öğretmen derse başlamadan önce bir önceki konuyu tekrar edip dersin sonunda konuyu özetlemiştir. Konunun özetlenmesine ilk 10. dakika ve son 15. dakikada yer verilmiştir.

Öğretmenin soru cevap yönteminde kullandığı bazı sorular; 'Ribozom nedir?, Küçük kan dolaşımı nedir?, Kan dolaşımı nasıl oluşur?, Kan dolaşımı nasıl bir yol izler?, Kaburga kemikleri vücudumuzun neredesindedir?, Çekirdeğin içinde bulunan maddeler nelerdir?, Akciğerlerde kan nasıl temizlenir?, İyonik bă̆ nedir? gibi bilgi düzeyinde, "Kan dolaşımı nasıl oluşur?, Işık olmayan bitki yaşayabilir mi?, Saf maddeye saf olmayan madde eklendiğinde donma noktası neden düşer? gibi kavrama düzeyinde ve Gece ve gündüz arasındaki sıcaklık farkının sebebi nedir? şeklinde analiz seviyesinde olduğu görülmüştür. Öğrencilerin sorduğu bazı sorular; Beslenme önemli midir?, Kalp krizi nasıl oluyor?, Kalp hiç yorulmaz mı?, Isınmaya termometrelerin rengi etkili mi?, Jimnastikçilerde kemik yok mudur? şeklindedir.

Gösteri deneyleri 5. ve 40. dakikalar hariç diğer dakikalarda kaynama noktası, 1sının yayılma yolları, maddenin halleri konusuna yönelik yapılmıştır. Öğretmenlerden biri sınıfı bahçeye çıkararak gölgedeki termometre ve güneşin altında bulunan termometre arasında ki sıcaklık farkını göstermiştir.

Öğretmenler örnek olay yöntemi içerisinde bulunan güncel hayattan örnekler vermeyi dersin her dakikasında yer vermişlerdir. Siyah giyinildiğinde daha çok terlenmesi, yoğurtun mayalanması, reçel yapımı, buzun erirken elin üşümesi, spor 
yaparken kasların yorulması, kışın yollara tuz dökülmesi bu konu ile ilgili verilen örneklerden bazılarıdır.

Problem çözme yöntemi kullanılırken öğrencilerden problemi çözmek için hipotez geliştirmesini isteme ise sadece 15. dakikada $1 \mathrm{kez}$ kullanılmıştır. Öğrencinin geliştirdiği hipotez; koyu renkli cisimler 1şı ğı açık renkli cisimlerden daha çok soğurur şeklindedir.

Öğretmenlerden çevresel imkânları kullanarak elde ettiği materyalleri derste kullanması 30. ve 35. dakikalarda sadece bir öğretmen tarafından gerçekleşmiştir. Su şişesi kapakları ve çubuklarla oluşturulan model ile su molekülünün moleküler yapısı gösterilmiştir.

Öğrenci özelliklerinin göz önünde bulundurularak rollerinin belirlenmesi, izleyici gruplara gözlem, canlandırılan rolleri gözlem gibi görevler verme dersin 25 . dakikasında 1'er kez kullanıldığı gözlemlenmiştir. Rol oynama "Vücudumuzdaki Sistemler" ünitesinde öğretmenin öğrencilere organların görevlerini paylaştırarak öğrencilerden organlar ile ilgili canlandırma yapması şeklinde gerçekleşmiştir ve rol oynama sonucunda öğretmen öğrencileri değerlendirmiştir.

Öğrencilere güncel konularla ilgili proje çalışması verme 20. 35 . ve 40 dakikalarda kullanılmıştır. Bu proje konuları "Kan Bağışı Kampanyası" ve "Sigarayı Birakma Kampanyası"dır.

\section{Öğretmenlerinin Öğretim Yöntem ve Teknikleri Konusundaki Bilgi Düzeyi ve Kullanma Sıklıklarının Karşılaştırılması}

Araştırmaya katılan öğretmenlerin öğretim yöntem ve teknikler konusunda sahip oldukları bilgi düzeyleri Tablo 2'de ve bunları kullanma sıklığı Tablo 3'te verilmiştir. $\mathrm{Bu}$ verilere baktığımızda anlatım yöntemi hakkında öğretmenler \%83.3 oranında iyi düzeyde bilgiye sahipken öğretmenlerın bu yöntemi derslerinde kullanma sıklığına bakıldğında \%16.7'sı çok seyrek, \%33.3'ü bazen derslerinde yer verdiklerini belitrmişlerdir. Ancak Tablo 5'te görüldüğü gibi gözlem formu verilerine göre ise kullanma sıklıklarında belirttikleri oranın aksine öğretmenler anlatım yöntemini derslerinin her dakikasında tamamına yakın kullanmışlardır.

Soru- cevap yönteminde öğretmenlerin sahip olduğu bilgi düzeyi ile kullanım sıklığına vermiş oldukları yanıtlar arasında paralellik bulunmaktadır. Gözlem formu da bunu destekler niteliktedir. Öğretmenler problem çözme yöntemiyle ilgili \%100 iyi düzeyde bilgi sahibiyken bu yöntemi derslerde kullanım sıklıkları \%33.3 bazen, \%66.7 oranında ise çoğu zaman kullanmaktadır. Öğretmenlerin belirttikleri kullanma sıklıkları ile sahip oldukları bilgi düzeyleri arasında belli bir farklılık yokken gözlem formunda kaydedilen verilere göre problem çözme yöntemin derslerinde kullanmaları en fazla $\% 25$ oranındadır.

Öğretmenler örnek olay yöntemini derslerinde \%33.3 oranında bazen kullanmaktayken bu yönteme ait sahip oldukları bilgi düzeyi ise $\% 83.3$ iyi düzeydedir. Öğretmenlerin sahip oldukları bilgi düzeyi yüksek oranda iyi olmasına rağmen 
öğretmenlerin belirttiği kullanma sıklıkları ve Tablo 5'te ifade edilen gözlem formu karşılaştırmasında örnek olaya çok fazla yer vermedikleri gözlemlenmiştir.

Öğretmenler rol oynama yöntemini kullanma sıklığı olarak \%33.3’ü çok seyrek \%33.3'ü bazen \%33.3'ü her zaman derslerinde kullandıklarını belirtmişlerdir. Bu yönteme dair sahip oldukları bilgi düzeyleri \%66.6 oranında iyidir. Ancak Tablo 5 'te görüldüğü üzere gözlem formunda kaydedilen bilgilere göre örnek olay yöntemini öğretmenler çok az kullanmaktadırlar. Bu durum sahip oldukları bilgi düzeyiyle çelişmektedir.

Öğretmenlerin laboratuar yöntemini kullanma sıklıkları \%33.3 bazen \%50 çoğu zaman \%16.7 her zamandır. Öğretmenlerin sahip oldukları bilgi düzeyi \%50 iyi düzeydedir. Öğretmenlerin kullanma sıklıklarına, sahip oldukları bilgi düzeyine ve gözlem formu verilerine bakıldığında bu verilerin de çeliştiği gözlemlenmiştir.

Öğretmenlerin proje yöntemini kullanma sıklıkları \%66.7 bazen \%33.3 çoğu zaman, bu yönteme dair sahip oldukları bilgi düzeyi \%66.7 iyi iken gözlem formunda kaydedilen verilere göre öğretmenler iyi düzeyde bilgi sahibi olmalarına karşın derslerinde kullanmaları çok düşük olarak tespit edilmiştir.

\section{Mülakatlardan Elde Edilen Bulgular}

\section{1. a. Fen öğretmenleriniz dersleri ne şekilde anlattyor?}

\section{b. Nasıl bir sunum öğrenmenizi daha etkili kılar?}

a. Mülakata katılan öğrencilerin \%92'si (6. sınıfların tamamı, 7. sinıflardan 48, 8. sınıflardan 39 öğrenci) öğretmenlerinin çoğu zaman anlatım yönteminin yanında soru cevap yöntemini de kullandıklarını belirtmişlerdir. 6. sınıflar anlatımın ve soru-cevap yönteminin çok sık kullanıldığı söylerken, 7. ve 8. sınıflar ise derste öğretmenin önemli noktaları yazdırdığını söylemiştir. Ayrıca öğrencilerin \%37'si (6. sınıftan 23, 7. sınıftan 18, 8. sınıftan 16 öğrenci) öğretmenlerinin öğrendiklerini unutmamaları için günlük hayattan örnekler verdiklerini ve böylece derslerinin daha eğlenceli geçmesini sağladıklarını belirtmişlerdir. 6. ve 7. sınıflar konuların kalıcı öğrenilmesinde günlük hayattan örnekler vermenin iyi olduğu söylemiş, 8. sinıflar ise derslerinin böyle işlenmesinin öğrenmelerine yardım ettiğini belirtmişlerdir. Öğrencilerin \%84’ü (6. sinıftan 46, 7. sinıftan 44, 8. sinıftan 40 öğrenci) öğretmenlerinin ders anlatırken bilgisayar destekli sunumdan faydalandıklarını söylemişlerdir. 6., 7. ve 8. sınıflar bilgisayar kullanarak görselleşmenin sağlandığını söylemişlerdir. Bunun yanında mülakata katılan öğrencilerin \%11'i (7. sınıftan 17 öğrenci) öğretmenlerinin bazı konuları önce kendilerine anlattırıp daha sonra konuyu kendisinin anlattığını belirtmişlerdir. $\mathrm{Bu}$ soruya ilişkin 7. sınıf öğrencilerinden birisinin görüşmeler esnasındaki ifadesi aynen şu şekildedir:

"Bu yll fen dersine giren ögrretmenimiz dönem başında bize ögrencilerin derste etkin olması gerektiğini söyleyerek bizim çalışarak derse gelmemizi istedi..... Bizlerden biri işlenecek konuyu öncelikle çalıştı̆̆ 
kadarlyla anlattyor, daha sonra ögretmenimiz sorular sorarak bizlerden gelen cevaplarla konuyu toparlayı sunuyor."

b. Öğrencilerin \%38'i (6. sinıftan 16, 7. sinıftan 20, 8. sinıftan 22 öğrenci) öğrenmede görselliğin önemli olduğunu bu yüzden öğretmenlerinin daha fazla görsel materyal kullanması gerektiğini ve deneylerin daha fazla yapılmasını istediklerini söylemişlerdir. 6. ve 7. sınıflar görsel materyalle konuları daha iyi anladıklarını söylemiş, 8. sınıflar ise çok az deney yaptıklarını belirtmiş ve daha fazla yapmak istediklerini dilegetirmişlerdir. Öğrencilerin \%14'ü (6. sınıftan 15, 7. sinıftan 17 öğrenci) öğretmenlerinin deney yaptıktan sonra konuyu vurgulayarak anlatması ile konuyu daha iyi öğrenebileceklerini ifade etmişlerdir. 8. sınıflar deney yapmak istediklerini söylerken 6 . ve 7. siniflar deneyden sonra tekrar konu anlatımının yapılması gerektiğini söylemişlerdir. Mülakata katılan öğrencilerin \%11'i (7. sınıftan 17 öğrenci) öğrenilen kavramların yerinde gözlem yapılabilmesi için gezi-gözlem yönteminin kullanılmasını istemektedirler. 7. sınıflar konuların yerinde işlenmesinin önemli olduğunu söylemişlerdir. Bu soruya yönelik 8. sınıf öğrencilerinden birisinin görüşmeler esnasındaki ifadesi aynen şu şekildedir:

"Öğretmenimiz her zaman fen derslerinin deneylere dayalı bir ders olduğunu söylemesine rağmen bizlere hemen hemen hiç deney yaptırmıyor. Biz istesekte bir ara yaparız diyerek geçiştiriyor."

\section{2. a. Laboratuara gidiyor musunuz?}

\section{b. Deneyleri siz mi yapıyorsunuz?}

c. Grupla mı deney yaptyorsunuz?

\section{d. Deney yapmayt seviyor musunuz?}

a. Mülakata katılan 6., 7. ve 8. sınıf öğrencileri derslerin laboratuarda işlendiğini fakat daha çok deney yapmak istediklerini belirmişlerdir.

b. $6 ., 7$. ve 8 . sinıf öğrencileri yaptıkları deneylerin ya öğretmenle birlikte yaptıklarını ya da öğretmenlerinin gösteri deneyi şeklinde yaptıklarını belirtmişlerdir. Bu soruya 6. sınıfta olan bir öğrencinin cevabı şu şekildedir:

“Öğretmenimiz deneyleri kendi yaparak bize gösteriyor. Bazen bizi gruplara ayırarak bizlerle birlikte de yapıyor."

c. Mülakatlara katılan tüm öğrenciler deneylerinin genellikle grupla yapıldı̆̆ını ve buna ek olarak malzeme yetersizliği nedeniyle öğretmenlerinin gösteri deneyini tercih ettiğini belirtmişlerdir. Bu konuda 8. sınıf olan bir grup öğrencinin (9 öğrenci) ortak cevabı şu şekildedir:

“.... fen ögretmenimiz okulumuzda kullanılabilecek araç-gereçlerin yeterli sayıda olmadı̆̆ından deney yapılmasını gerektiren konularda çoğu zaman gösteri deneyini tercih ediyor..... Bazende çocuklar zaman çok yok ben size bu deneyi gösteri deneyi olarak yapacağım iyi izleyin diyor." 
d. Kendileriyle görüşülen 6., 7. ve 8. sınıf öğrencileri deney yapmayı çok sevdiklerini fakat öğretmenlerinin öğrencilere yeteri kadar deney yaptırmadıklarını belirtmişlerdir.

\section{Derslerinizde Bilgisayar, TV, poster kullanıyor musunuz?}

Öğrenci görüşlerinden elde edilen veriler analiz edildiğinde hiçbir okulda televizyon kullanılmazken okulun olanaklarına göre bilgisayar, poster ve modellerden yararlanıldığı anlaşılmıştır. Ayrıca öğrenciler, örneklemimizde yer alan bir okulda televizyon ve projeksiyon cihazının olmadığını bu yüzden kullanamadıklarını fakat projeksiyon kullanıldığında daha etkili öğrenebileceklerini vurgulamışlardır. Bu soruya 8. sınıfta olan bir öğrencinin cevabı şu şekildedir:

“... ben bu okulda $\ddot{u} c ̧$ yıldır okuyorum ama derslerde ögretmenlerimizin televizyon kullandı̆̆ını hiç görmedim, zaten gerek olduğunu da düşünmüyorum. Öğretmenimiz bir konu hakkında bize film ya da bir şey izletecekse eğer bunu bilgisayar yardımı ile projeksiyon cihazı ile duvara yansitlyor."

\section{4. Ö̆̆retmeniniz proje ödevi veriyor mu?}

Mülakata katılan öğrencilerin \%60’1 (6.sınıftan 32, 7.sınıftan 35, 8.sınıftan 25 öğrenci) öğretmenlerinin proje ödevi verdiklerini belirtmişlerdir. Bunun yanında başarı seviyesi düşük sınıflardaki öğrenciler proje ödevi yapmayı sevmediklerini çeşitli nedenlerle belirtmişlerdir. Proje ödevi vermeyi tercih etmeyen öğretmenlerin not ortalaması düşük olan öğrencilere not ortalamalarını yükseltmeleri için proje ödevi alabilme firsatı tanıdıkları elde edilen bulgular arasındadır. Bu konuda 7. sınıfta olan bir öğrencinin cevabı şu şekildedir:

“... Öğretmenim bizim sinıf diğer sınıfa göre biraz daha başarısız bir sınıf. Fencimiz dönem sonunda bizim internetten veya çevremizden kolay ulaşabilip yapabileceğimiz proje ödevleri vererek notlarımızın yükselmesini istiyor."

\section{Derslerinizde öğretmeniniz konuları günlük hayatla ilişkilendiriyor mu?}

Mülakata katılan öğrenciler öğretmenlerinin ders anlatımlarında günlük hayatla ilişki kurarak konuları işlediklerini belirmişlerdir. Öğrenciler, öğretmenlerinin dersleri bu şekilde anlatması durumunda daha kolay öğrendiklerini ve kalıcı bilgiler edindiklerini belirtmişlerdir. Bu soruya 7. sınıf öğrencilerinden biririnin özellikle verdiği cevap şu şekildedir:

"Derste ögrretmenimiz basit makinelerde kaldıraçlardan bahsederken tattaravalli, makas, ceviz kıracă̆ını örnek olarak verdiğini hatırliyorum."

6. Fen bilimleri öğretmenlerinizin dersi yürütürken farklı bir uygulamasını hattrlyor musunuz? 
Mülakata katılan öğrencilerin \%83'ü (6. sinıftan 43, 7. sinıftan 46, 8. sinıftan 39 öğrenci) derste farklı bir etkinlik yapmadıklarını, öğretmenlerinin dersi hep aynı şekilde işlediklerini belirtmiştir. Öğrencilerin \%17'si (6. sınıftan 11, 7. sınıftan 6, 8. sınıftan 9 öğrenci) ise derste konuyla ilgili kavramlarla drama yaptıklarını ve birkaç kez dersi bahçede işlediklerini belirtmiştir. Mülakata katılan öğrenciler farklı uygulamalar aracılığı ile işlenen konuları unutmadıklarını ifade etmişlerdir. Bu konuda 8. sınıf öğrencilerinden biririnin özellikle verdiği cevap şu şekildedir:

"Okulun başlarında hücre bölünmesi konusuyla ilgili sınıfta arkadaşlarımızla bir drama yapmıştık hiç unutamıyorum çok eğlendik."

\section{Sonuç ve Tartışma}

Yapılan çalışmada fen bilimleri öğretmenlerinin anlatım yöntemini sık kullandıklarının tespit edilmesinin yanında bu yöntemi soru-cevap, gösteri, örnek olay yöntemi ve problem çözme yöntemi ile pekiştirdikleri görülmektedir. Bunun sebebi öğretmenlerin araç-gereç kullanmadan derslerini işlemek istemesi, bunu yaparken öğrencilerle iletişim kurmak için soru sorması, işlediği konulara yönelik problem çözmesi ve günlük hayattan örnekler vermeyi tercih etmesi olabilir. Öğretmenler problem çözme yöntemini konuyla ilgili sorular çözme ve örnek olay yöntemini ise günlük hayattan örnekler verme şeklinde görmektedir. Öğretmen soru cevap yöntemini kullanırken önceden soru hazırlamamakta, soruları dersin akışına göre sorarak yürütmektedir. İlgili literatür incelendiğinde benzer verilerin elde edildiği görülmüştür (Aktepe ve Aktepe 2009; Aydede, Çağlayan, Matyar ve Gülnaz, 2006; Demirezen, 2001; Doğru, 2000; Ekici, 1996; Temizöz ve Özgün-Koca, 2008; Yaman, 2000). Aktepe ve Aktepe (2009) çalışmalarında fen öğretmenlerinin derslerinde en sık kullandıkları yöntemin anlatım ve yine laboratuar ve soru cevap yöntemlerinin de sıklıkla kullanılanlar arasında olduğunu tespit etmişlerdir. Aydede, Çağlayan, Matyar ve Gülnaz (2006) yaptıkları bir çalışmada, fen öğretmenlerinin çoğunun anlatım yöntemini kullanmasının yanında, bu yöntemi soru-cevap, beyin firtınası, tartışma, laboratuvar ve problem çözme gibi öğrenci merkezli yöntemlerle desteklediklerini belirtmişlerdir. Temizöz ve Özgün-Koca (2008) matematik öğretmenlerinin derslerini büyük oranda anlatım ve soru-cevap yöntemleriyle işlediklerini ortaya koymuştur.

Çalışmaya katılan öğretmenler anlatım yöntemini çok iyi bildiklerini fakat çoğunun orta düzeyde kullandıklarını belirtmişlerdir. Yapılan mülakatlarda öğrenciler öğretmenlerinin dersi genellikle anlatım yöntemi ile işlediklerini belirtmişlerdir. Aynı zamanda araştırmacılar tarafindan uygulanan gözlem formunun da anlatım yönteminin bütün derslerde kullanıldığını göstermesi, öğretmenlerin anlatım yöntemi kullanma sıklığı ile ilgili mülakat ve gözlemlerden elde edilen bulgular ile çelişmektedir. Bu durum öğretmenlerin anlatım yöntemini sıklıkla kullandıklarının farkında olmalarına rağmen, öğretmen merkezli olan bu yöntemi kullandıklarını ifade etmekten çekinmelerinden kaynaklanabilir. Aynı zamanda öğretmenler soru cevap yöntemi ile ilgili yüksek düzeyde bilgiye sahip olmasından dolayı bu yöntemi iyi derecede kullanmaktadırlar. 
Öğretmenler gösteri yöntemini uygularken öğrencilerin birden fazla duyu organına hitap etmek için genellikle bilgisayar destekli sunumdan faydalanmıştır. Öğretmenlerin dersi konu ile ilişkilendirmek için orta düzeyde örnek olay yönteminden yararlandığı, yapılan mülakatta bu yöntemin öğrencilerin kavramları günlük hayatla ilişkilendirmesine ve bilgilerin daha kalıcı olmasına etki ettiği dikkat çekmektedir. Bunun sebebi öğrencilerin günlük hayatla ilişkili kavramları merak etmesi ve öğrenilen bilgiler ile günlük hayatla ilişki kurarak bu kavramlar aklına geldiğinde zihninde anlamsal çağrışım yaparak hatırlaması olabilir. Bilindiği gibi, öğrencilerin fen okuryazarı olarak yetiştirilmesinde bilgilerini günlük hayatla ilişkilendirmeleri oldukça önemlidir (Harlen, 2002). Eğer öğrenmeye yapısalcı görüşle bakarsak; öğrencilerin günlük yaşamlarındaki ön deneyimleri öğrenme etkinliklerinin başlangıcını oluşturmaktadır (Andrée, 2003).

Öğretmenlerin gezi gözlem yöntemi ile ilgili orta düzeyde bilgilerinin olmasına rağmen gezi gözlem yönteminin çok az kullanıldığı görülmüştür. $\mathrm{Bu}$ durum öğretmenlerin gezi-gözlem yöntemini nasıl uygulanacağını tam bilmemesinden, gerekli imkânları oluşturamamasından ve yasal sorumluluk almaktan kaçınmalarından kaynaklanabilir. İlgili literatür incelendiğinde benzer sonuçlar görülebilir (Bulut, 2010; Kumbiçak, Atılboz ve Salman, 2006).

Öğretmenlerin çoğunun rol oynama yöntemi ile ilgili iyi düzeyde bilgiye sahip olduklarını belirtmelerine rağmen derslerinde bu yöntemi çok az kullandıkları gözlem formun ve mülakattan elde edilen bulgularda görülmüştür. Öğretmen zamanı ayarlama konusunda ve sınıf yönetiminin zorlaştığından dolayı da bu yöntemi tercih etmediği söylenebilir. İlgili literatür incelendiğinde benzer sonuçlar görülebilir (Karamustafaoğlu ve Yaman, 2014). Aynı şekilde, Geçer ve Özel (2012)'in fen öğretmenleri üzerinde gerçekleştirdikleri bir çalışmada rol oynama yönteminin öğretmenler tarafindan çok nadir kullanıldığııı ortaya koymuştur.

Öğretmenlerin öğrencileri merkeze alan tartışma, laboratuar, rol oynama, proje yöntemleri ile ilgili orta düzeyde bilgileri olmalarına rağmen gözlem formu ve anket verileri incelendiğinde öğretmenlerin derslerinde bu yöntemlere az yer verdikleri görülmüştür. Öğretmenlerin bu yöntemleri sık kullanmamasının nedeni bu yönteme yönelik yeni yaklaşımları bilmemesinin yanında bu yöntemlerin hazırlık gerektirmesi, zaman sıkıntısı ve sınıfların kalabalık olmasından kaynaklanmış olabilir. İlgili literatür incelendiğinde buna ilişkin sonuçlar görülmektedir (Dindar ve Yaman, 2002; Savaş, 2002; Sözbilir, Şenocak ve Dilber, 2006).

Yapılan mülakatlarda öğrenciler, öğretmenlerin dersleri laboratuarda işlemelerine karşın çok az deney yaptıklarını ve bu deneyleri gösteri deneyi şeklinde gerçekleştirdiklerini belirtmişlerdir. Öğrenciler deney yapılarak işlenen derslerde konuyu daha iyi öğrendiklerini belirterek yaparak yaşayarak öğrenmenin önemini vurgulamışlar. Ancak öğretmenler malzeme yetersizliğinden ve okulun fiziki imkânlarından dolayı bu yöntemi sık kullanamadıklarını belirtmişlerdir. Bu bulgular Kaptan ve Korkmaz (2001) ve Kumbıçak, Atılboz ve Salman (2006)'ın çalışmaları ile paralellik göstermektedir. 
Proje çalışmalarının okullarda uygulanması öğretim sürecine olumlu katkı sağlayacaktır. Ancak, eğitim sistemimizdeki bazı aksaklıklardan dolayı proje çalışmalarının birçok eğitim kurumunda uygulanamamaktadır (Çepni, 2010). Bu bağlamda proje yöntemi öğrencilerin isteksizliği, öğretmenlerin ise öğrencilerin notlarını yükseltmek amaçlı kullanmaktan öteye gitmediği gibi sorunlardan dolayı az kullanıldığı anlaşılmaktadır.

Öğretmenlere uygulanan anket verileri ile gözlem formu verileri paralellik göstermesine karşın, özellikle münazara, gösteri, mikro öğretim, altı şapkalı düşünme tekniği ve çember tekniğini kullanmadıkları, kavram haritası ile işbirlikli öğrenme tekniğine ise çok az kullandıkları gözlemlenmiştir. Bunun durum, öğretmenlerin bu yöntemlerle ilgili fazla bilgi sahibi olmamalarından kaynaklanabilir. Farklı bir alanda benzer bir çalışma yürüten Aykaç (2011)’’n, paralel verilere ulaştığı tespit edilmiştir.

Öğretmenler fen bilimleri eğitimi açısından en etkili yöntem sorusuna farklı cevaplar vermiştir. Bu duruma öğretmenin yönteme olan yatkınlığı, öğrenci grubunun büyüklüğü, fiziki imkânlar etki etmiş olabilir. İlgili literatür incelendiğinde benzer sonuçlara varıldığı görülmüştür (Küçükahmet, 1997).

Yapılan gözlemler ile mülakatlar incelendiğinde bazı öğretmenler dersi yürütürken öğrencilere ders anlattırmayı tercih etmektedir. Bu durum fen bilimleri öğretmenlerinin yeni fen bilimleri dersi öğretim programında yer alan “öğrenci merkezli eğitim" kavramını yanlış anlamalarından kaynaklanabilir. Öğretmenin öğrencilere bilgiyi keşfetmelerine rehberlik etmeleri gerekirken tüm sorumluluğu öğrencilere yüklemesi işlenen konunun tam anlaşılamamasına yol açabilir.

Araştırmada, öğrencilerin görüşlerine göre fen bilimleri öğretmenlerinin fen öğretiminde en sık kullanmasını istedikleri yöntemlerin, laboratuar, sınıfta gösteri deneyi ve doğa olayları hakkında okul dişı gezi-gözlem yapma olduğu sonucuna varılmıştır. Öğrencilerin bu yöntemleri tercih etmeleri, aktif olarak katıldıkları öğretim etkinliklerinde eğlenerek anlamlı ögrenmeyi sağlamalarından kaynaklanmaktadır. İlgili literatür incelendiğinde benzer sonuçlar görülebilir (Aktepe \& Aktepe, 2009).

\section{Öneriler}

Araştırmacılar çalışma bulguları doğrultusunda Programlar ne kadar iyi hazırlanırsa hazırlansın ögretimde yöntem ve tekniklerinin uygulamalar etkili olmadıkça belirlenen hedeflere istenen düzeyde ulaşılamaz sonucuna varmışlardır. Bu bağlamda, Fen öğretiminde istenen hedeflere ulaşılabilmesi için sonuçlara dayalı öneriler aşağıda sırasıyla sunulmuştur:

1. Fen bilimleri derslerinin eğitim teknolojileri ve materyal destekli bir şekilde yürütülmesi konusunda öğretmenler cesaretlendirilmelidir.

2. Proje temelli yaklaşım ile fen öğretiminin etkililiği hakkında öğretmenler bilinçlendirilmelidir.

3. Fen öğretimi "aktif öğrenme ve öğretme" ilkesine göre yürütülmeli, drama ve gezi gözlem yöntemleri daha sıklıkla kullanılması konusunda farkındalık sağlanmalıdır. 
4. Fen bilimleri öğretmenlerinin, öğretim yöntem ve teknikleri ile uygulamalarına yönelik hizmet-içi eğitimle bilgi ve becerilerinin güncellenerek geliştirilmesi sağlanmalıdır.

5. Basit araç gereç ve materyal hazırlama ile geliştirme yöntemleri hakkında özellikle on beş yıldan daha deneyimli öğretmenler hizmet-içi eğitim kursları ile mutlaka bilgilendirilmelidir. Böylece araç gereçlerin yeteri kadar olmadığı durumlarda öğretmenler basit araç gereç ve materyalleri kullanarak görselliği sağlayabilirler.

6. Öğretmen adaylarına hizmet öncesi eğitimleri süresince laboratuar derslerinin önemli olduğu bilinci kazandırılmalıdır.

7. Hizmet öncesi eğitim sürecinde, öğretmen adaylarının kuramsal bilgiler yerine günlük hayatta kullanabilecekleri ve uygulamalı bilgilerle donatılması sağlanmalıdır.

8. Okullar fen öğretimi ve laboratuarları araç-gereç ve materyaller bakımından yenilenmeli ve geliştirilmelidir.

9. Öğretmenler gezi-gözlem gibi yöntem ve tekniklere derslerinde yer vererek, gerçek durum, nesne ve objeleri öğrencilerin yerinde incelenmesine firsat tanımalıdır.

10. Bu çalışma konusuna ilgi duyan araştırmacılar, farklı alanlarda, farklı illerde benzer araştırmalar yaparak elde edecekleri sonuçları bu araştırmada ulaşılan sonuçlarla karşılaştırabilirler.Ayrıca araştırmada elde edilen sonuçlara ilişkin öneriler de Öneriler alt başlığı altında verilmelidir. 


\section{Kaynakça}

Aktepe, V. ve Aktepe, L. (2009). Fen ve teknoloji öğretiminde kullanılan öğretim yöntemlerine ilişkin öğrenci görüşleri: Kırşehir Bilsem örneği, Ahi Evran Üniversitesi Kırşehir Ĕ̈itim Fakültesi Dergisi, 10(1), 69-80.

Andrée, M. (2003, August). Everyday-Life in the science classroom: A study on ways of using and referring to everyday-life. Oral presentation, ESERA Conference. Noordwijkerhout, the Netherlands.

Ayas, A., Çepni, S., Akdeniz, A.R., Özmen, H., Yiğit, N., \& Ayvacı, H. Ş. (2005). Kuramdan uygulamaya fen ve teknoloji ögretimi. (3. Baskı). Ankara: Pegem A Yayıncilik.

Aydede, M.N., Çağlayan, Ç., Matyar, F., \& Gülnaz, O. (2006). Fen ve teknoloji öğretmenlerinin kullandıkları öğretim yöntem ve tekniklerine ilişkin görüşlerinin değerlendirilmesi. Çukurova Üniversitesi Eğitim Fakültesi Dergisi, 3(32), 24-33.

Aykaç, N. (2011). Hayat bilgisi dersi öğretim programında kullanılan yöntem ve tekniklerin öğretmen görüşlerine göre değerlendirilmesi (Sinop ili örneği), Kastamonu Eğitim Dergisi, 19(1), 113-126.

Bulut, G. (2010). Illköğretim (6-7-8. sinıf) fen ve teknoloji öğretmenlerinin öğretim yöntem ve tekniklerini kullanma alışkanlıkları (Hatay ili örneği) (Yayınlanmamış yüksek lisans tezi). Furat Üniversitesi, Elazı ̆.

Büyüköztürk, Ş., Kılıç Çakmak, E., Akgün, Ö. E., Karadeniz, Ş., \& Demirel, F. (2008). Bilimsel araştırma yöntemleri. Ankara: Pegem A Yayınları.

Cohen, L. ve Mannion, L. (1994). Research methods in education. London and New York: Routledge.

Çepni, S. (2010). Araştırma ve proje çalışmalarına giriş. (5. Baskı). Trabzon: Celepler Matbaacilik.

Çepni, S. Ayas, A. Johnson, D., \& Turgut, F. (1997). Fizik öğretimi. YÖK/Dünya Bankası Milli Eğitimi Geliştirme Projesi Hizmet Öncesi Öğretmen Eğitimi.

Demirel, Ö. (2003). Kuramdan uygulamaya ĕgitimde program geliştirme. (5. Bask1). Ankara: Pegem A Yayıncılık.

Demirezen, S. (2001). Sinıf ögrretmenlerinin öğretim stratejileri ile öğretim yöntem ve tekniklerine ilişkin görüşleri (Yayınlanmamış yüksek lisans tezi). Hacettepe Üniversitesi, Ankara.

Dindar, H., \& Yaman, S. (2002). Öğretmenlerin ilköğretim 4. ve 5. sınıflarda fen ve teknoloji dersinde öğretim yöntemlerini kullanma durumları. Kastamonu Eğitim Dergisi, 10(1), 103-108.

Doğru, M. (2000). Fen bilgisi öğretiminde kullanılan yöntemlerde karşılaşılan sorunlar (Yayınlanmamış yüksek lisans tezi). Gazi Üniversitesi, Ankara. 
Doğru, M., \& Aydoğdu, M. (2003). Fen bilgisi öğretiminde kullanılan yöntemlerde karşılaşılan sorunlar ile ilgili öğrenci görüşleri. Pamukkale Üniversitesi Eğitim Fakültesi Dergisi, 13(1), 150-158.

Ekici, G. (1996). Biyoloji öğretmenlerinin öğretimde kullandıkları yöntemler ve karsılaştıkları sorunlar (Yayınlanmamış yüksek lisans tezi). Ankara Üniversitesi, Ankara.

Erdem, M. (1997). Sosyal bilgiler ögretimi. Ankara: Alkım Yayınevi.

Erginer, E. (2000). Öğretimi planlama uygulama ve değerlendirme. Ankara: Anı Yayıncilik.

Ertürk, S. (1972). Eğitimde program geliştirme. Ankara: Yelkentepe Yayınları.

Geçer, A., \& Özel, R. (2012). İlköğretim fen ve teknoloji dersi öğretmenlerinin öğrenme-öğretme sürecinde yaşadıkları sorunlar. Kuram ve Uygulamada Ĕ̆itim Bilimleri, 12(3), 1-26.

Harlen, W. (2002). Links to everyday life: The roots of scientific literacy. Primary Science Review, 71, 8-10.

Hesapçıŏlu, M. (1998). Öğretim ilke ve yöntemleri, ĕgitim programları ve ögretim. (5. Bask1). İstanbul: Beta Basın Yayın ve Dağıtım.

İlhan, B. (2006). Müfredat laboratuar ilköğretim okullarında 6. 7. ve 8. sinıflarda görev yapan alan ögretmenlerinin küçük grupla öğretim yöntem ve tekniklerini uygulama durumları. (Yayınlanmamış yüksek lisans tezi). Anadolu Üniversitesi, Eskişehir.

Kaptan, F. (1999). Fen bilgisi ögretimi. İstanbul: MEB Yayınları.

Kaptan, F., \& Korkmaz, H. (2001). İlköğretim okullarında fen bilgisi dersinin uygulanmasında karş1laşılan güçlükler. Çă̆daş Eğitim, 281, 19-26.

Kaptan, F., \& Korkmaz, H. (2002). Fen eğitiminde proje tabanlı öğrenmenin yaratıcı düşünme, problem çözme ve akademik risk alma düzeylerine etkisi. Hacettepe Üniversitesi Ĕ̆itim Fakültesi Dergisi, 22, 164-170.

Karamustafaoğlu, O., \& Yaman, S. (2014). Fen eğitiminde özel öğretim yöntemleri I-II. (5. Bask1). Ankara: Anı Yayıncılık.

Kumbıçak, Ü., Atılboz, N. G., \& Salman, S. (2006). İlköğretim okullarındaki fen bilgisi dersinde yer alan biyoloji konularının öğretiminde karşılaşılan sorunlar. Milli Ĕ̈itim Dergisi, 172, 211-224.

Küçükahmet, L. (1997). Eğitim programları ve ögretim. (8. Bask1). Ankara: Gazi Kitapevi.

Küçükahmet, L. (2005). Öğretimde planlama ve değerlendirme. (17. Bask1). Ankara: Nobel Yayın Dağıtım.

MEB (2013). Ilköğretim kurumlart (ilkokullar ve ortaokullar) fen bilimleri dersi ögretim programı. T.C. Milli Eğitim Bakanlığı Talim ve Terbiye Kurulu Başkanlığı, Ankara.

Merriam, S. B. (1988). Case study research in education: A qualitative approach. London: Jossey-Bass Publishers. 
Savaş, N. (2002). İlköğretim fen ögrretiminde, ögrretmenlerin izlediği ögrretim yöntemleri ve bu yöntemlerin ögrenci başarısına etkisi. (Yayınlanmamış yüksek lisans tezi). Gazi Üniversitesi, Ankara.

Solmaz, A. (2007). Fen bilgisi ögrretiminde kullanılan ögrretim yöntemleri ve yöntemlerin uygulanışına ilişkin ögrrenci görüşleri. (Yayımlanmamış yüksek lisans tezi). Gazi Üniversitesi, Ankara.

Sözbilir, M., Şenocak, E., \& Dilber, R. (2006). Öğrenci gözüyle fen bilgisi öğretmenlerinin derslerinde kullandıkları öğretim yöntem ve teknikleri. Milli Ĕ̈itim Dergisi, 172, 276-286.

Tan, Ş. (2007). Öğretim ilke ve yöntemleri. Ankara: Pegem A Yayıncılık.

Taşpınar, M. (2007). Öğretim ilke ve yöntemleri. Ankara: Nobel Yayınları.

Temizöz, Y., \& Özgün-Koca, A. S. (2008). Matematik öğretmenlerinin kullandıkları öğretim yöntemleri ve buluş yoluyla öğrenme yaklaşımı konusundaki görüşleri. Ĕgitim ve Bilim, 33(149), 89-103.

Tutkun, Ö.F., Koç, M., Sezer, A., \& Polat, Ü. (2004). Gelişen ve değişen konjuktürde türk milli eğitim sisteminde okul ve öğretmen profili. XIII. Ulusal Ĕ̆itim Bilimleri Kurultayl, İnönü Üniversitesi, Malatya.

Yaman, S. (2000). Illköğretim okullarında görev yapan öğretmenlerin 4. ve 5. sinıflarda fen bilgisi dersinde öğretim yöntemlerini kullanma durumlarına yönelik bir araştırma. (Yayınlanmamış yüksek lisans tezi). Gazi Üniversitesi, Ankara.

Yin, R. K. (2009). Case study research: design and methods. (4 ${ }^{\text {th }}$ Ed.). California: Thousand Oaks, Sage Publications.

Young, B.J., \& Kellogg, T. (1993). Science attitudes and preparation of preservice elementary teachers. Science Education, 77(3), 279-291. 